\title{
Investigation of the Roman period pottery production technology from the Seyitömer Mound (Kütahya/Turkey)
}

\author{
V. Uz ${ }^{1}$, S. Deniz ${ }^{1}$, A. İssi ${ }^{1}$ \& A. N. Bilgen ${ }^{2}$ \\ ${ }^{I}$ Department of Materials Science and Engineering, \\ Dumlupinar University, Turkey \\ ${ }^{2}$ Department of Archaeology, Dumlupinar University, Turkey
}

\begin{abstract}
The pottery sherds of the Roman period which is the subject of the paper were found at the rescue excavation held in 1989 on site of Seyitömer Mound (Kütahya/Turkey). This study represents archaeometrical analyses of 30 pottery sherds found in the Seyitömer Mound. The important clues for the detection of production and distribution areas of the Roman period sherds were attained in the archaeometrical studies carried out in recent years. A wide variety of characterization techniques were performed. Wavelength dispersive X-ray fluorescence (WDXRF) was performed for chemical analysis, X-ray diffraction (XRD) was performed for mineralogical and phase analysis of the pottery sherds. Scanning electron microscopy (SEM) and microanalysis technique (EDX) were performed for microstructural and microchemical analysis. Thermogravimetricdifferential thermal analysis (TG-DTA) was employed for the estimation of firing temperature. Raw materials used for the production, firing temperatures and conditions for the pottery sherds were discussed in the study. From the results obtained, ceramic bodies have been produced from clay deposits rich in iron, containing illitic type minerals and carbonated minerals such as calcite and dolomite. Three groups were concluded as starting raw materials which are rich in calcite, magnesium and siliceous minerals. Firing temperatures of the potsherds change from $600^{\circ} \mathrm{C}$ to $1100^{\circ} \mathrm{C}$.

Keywords: Seyitömer Mound, Roman period, ceramic artifact, characterization, archaeometry.
\end{abstract}




\section{Introduction}

Physical and chemical identification of archaeological objects may give a lot of information about ancient civilizations. One of these objects is ceramic. Ceramics used in ancient times could survive till today because of their durability obtained by firing above $400^{\circ} \mathrm{C}$. That is why in archaeological excavations, the most recovered materials are ceramics. Investigation of a piece of ceramic could help to reach the information of raw materials, production processes, date and place of production. There are many characterization techniques in a wide variety of enlightening the production technology (Papachristodoulou et al. [1], Barone et al. [2]).

The Seyitömer Mound is located $25 \mathrm{~km}$ northwest of the centre of Kütahya (Turkey). The Mound is 150x140 m in size and have height of $23.5 \mathrm{~m}$. In order to receive 12 million tonnes of coal reserve under the mound, archaeological excavations is being held in the archaeological site. The archaeological excavations were started under the leadership of Prof. Dr. A. Nejat Bilgen from Department of Archaeology of Dumlupinar University in 2006 after the excavations started in 1989 for a couple of years. It has been enlightened that the Seyitömer Mound has been inhibited by civilizations in the Bronze Age, Achaemenid, Hellenistic and Roman periods (Bilgen [3]). 30 pottery sherds unearthed in the Seyitömer Mound belonging to the Roman period have been investigated. Chemical analysis of samples was performed by wavelength dispersive X-ray fluorescence (WDXRF) and mineralogical/phase composition analysis was performed by X-ray diffraction (XRD) (Vinagre et al. [4], Demirel et al. [5], Kennett et al. [6]) to perform archaeometrical characterization of the artifacts. Scanning electron microscopy (SEM) and energy dispersive spectroscopy (EDS) used for identification of microstructural and microchemical properties of the samples. Thermogravimetric-differential thermal analysis (TGDTA) was performed to observe the thermal behaviors of the samples to predict the maximum firing temperatures.
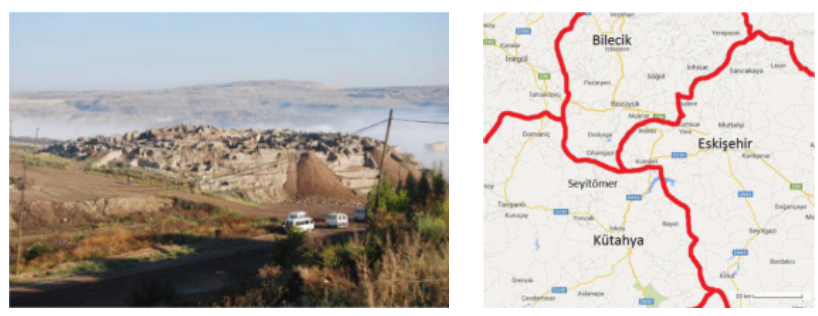

Figure 1: A photograph and a map showing the location of the Seyitomer Mound.

\section{Materials and methods}

The representative photos of the Roman period samples coded as R17, R18, R19 and R25 were given in Figure 2. 


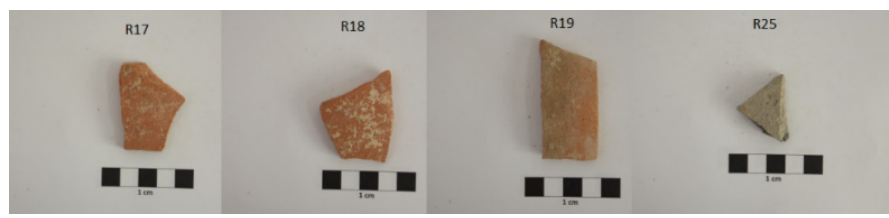

Figure 2: $\quad$ Photos of R17, R18, R19 and R25 coded samples.

Determined parts of the samples were cut by diamond cutting discs and $0.8-$ $1.5 \mathrm{~g}$ of samples were obtained. Samples were stored in deionized water to remove impurities for 2 days. Cleaned samples were dried at room temperature. Powder of the samples was prepared in agate mortars to perform the analysis. A Rigaku Miniflex powder diffractometer with $\mathrm{Cu} \mathrm{K \alpha}$ radiation $(\lambda=1.5418 \AA)$ was used for the mineralogical analysis. XRD patterns were obtained by scanning $5^{\circ}$ to $55^{\circ}$ in $2 \theta$, with a goniometer speed of $2 \% \mathrm{~min}$, operating at $40 \mathrm{kV}$ and $30 \mathrm{~mA}$. The interpretation of mineralogical content of the data was conducted with JADE 7 software by searching and matching the powder diffraction files. A Rigaku ZSX primus wavelength dispersive X-ray fluorescence (WDXRF) instrument was used for chemical analysis of the elements. The measurements were carried out on glass tablets prepared by fluxing powdered samples with $\mathrm{Li}_{2} \mathrm{~B}_{4} \mathrm{O}_{7}$ in 1:10 weigh ratio. The calculation of the semi-quantitative results was conducted with ZSX software. The results were given as oxides. The microstructural and microchemical aspects of the representative potsherds were investigated using FEI Nova Nano 650 SEM instrument which also includes an EDS detector. Setaram Labsys Evo instrument was used for TG-DTA analysis. A heating rate of $10^{\circ} \mathrm{C} / \mathrm{min}$ was performed in oxidative atmosphere from room temperature to $1200^{\circ} \mathrm{C}$.

\section{Results and discussions}

\subsection{Chemical analysis result and discussion}

Instead of giving all the results of the study, chemical analysis results belonging to R17, R18, R19 and R25 which are calcium poor and rich and representing chemical analysis of ceramic groups were given in Table 1.

As seen from the results, maximum percentage of $\mathrm{CaO}$ belongs to $\mathrm{R} 25$ coded sample, minimum percentage belongs to R17 coded sample. Considering total of alkaline and alkaline-earth oxides, R25 have the maximum quantity.

\subsection{Mineralogical/phase analysis results and conclusions}

XRD results belong to R17, R18, R19 and R25 coded samples given in Table 2. Determined phases are: Quartz $\left(\mathrm{SiO}_{2}\right)$, Plagioclase, Illite $\left(\left(\mathrm{K}, \mathrm{H}_{3} \mathrm{O}\right) \mathrm{Al}_{2} \mathrm{Si}_{3} \mathrm{AlO}_{10}(\mathrm{OH})_{2}\right)$, Microcline $\left(\mathrm{KAlSi}_{3} \mathrm{O}_{8}\right)$, Calcite $\left(\mathrm{CaCO}_{3}\right)$, Gehlenite $\left(\mathrm{Ca}_{2} \mathrm{Al}_{2} \mathrm{SiO}_{7}\right)$, Kaliophilite $\left(\mathrm{KAlSiO}_{4}\right)$, Augite $(\mathrm{Ca}(\mathrm{Mg}, \mathrm{Fe}) \mathrm{SiO} 2 \mathrm{O} 6)$, Wollastonite $\left(\mathrm{CaSiO}_{3}\right)$, Akermanite $\left(\mathrm{Ca}_{2} \mathrm{MgSi}_{2} \mathrm{O}_{7}\right)$, Hematite $\left(\alpha-\mathrm{Fe}_{2} \mathrm{O}_{3}\right)$, Maghemite $\left(\gamma-\mathrm{Fe}_{2} \mathrm{O}_{3}\right)$, Augite $\left(\mathrm{Ca}(\mathrm{Mg}, \mathrm{Fe}) \mathrm{SiO}_{2} \mathrm{O}_{6}\right)$. XRD analysis results of R17, R18, R19, R25 coded samples and raw materials of clays are given in Table 2 . 
Table 1: Chemical analysis results of R17, R18, R19 and R25. The term of "n.d." indicates not detected or under the limits of detection by WDXRF technique performed.

\begin{tabular}{|c|c|c|c|c|}
\hline \multirow[b]{2}{*}{ Oxide } & \multicolumn{2}{|c|}{ Calcium Poor } & \multicolumn{2}{|c|}{ Calcium Rich } \\
\hline & R17 & R18 & R19 & R25 \\
\hline $\mathrm{Na}_{2} \mathrm{O}$ & 0.858 & 3.1708 & 2.127 & 2.847 \\
\hline MgO & 0.9629 & 0.871 & 4.1693 & 5.1154 \\
\hline $\mathrm{Al}_{2} \mathrm{O}_{3}$ & 18.0834 & 17.6805 & 15.02 & 18.2039 \\
\hline $\mathrm{SiO}_{2}$ & 68.2511 & 66.1349 & 58.2277 & 52.6488 \\
\hline $\mathrm{P}_{2} \mathrm{O}_{5}$ & 0.0754 & 0.0651 & 0.1493 & 0.2683 \\
\hline $\mathrm{SO}_{3}$ & 0.0173 & 0.0514 & 0.0867 & 0.13 \\
\hline Cl & n.d. & 0.2851 & 0.1571 & 0.1895 \\
\hline $\mathrm{K}_{2} \mathrm{O}$ & 2.0751 & 2.0835 & 2.3857 & 3.0074 \\
\hline $\mathrm{CaO}$ & 0.5668 & 0.5293 & 6.4215 & 9.3013 \\
\hline $\mathrm{TiO}_{2}$ & 0.9155 & 0.9445 & 0.7917 & 0.8282 \\
\hline $\mathrm{Cr}_{2} \mathrm{O}_{3}$ & 0.0487 & 0.0564 & 0.3285 & 0.0711 \\
\hline MnO & 0.137 & 0.1609 & 0.1421 & 0.1595 \\
\hline $\mathrm{Fe}_{2} \mathrm{O}_{3}$ & 7.8539 & 7.8184 & 9.5029 & 7.0505 \\
\hline $\mathrm{NiO}$ & 0.0242 & 0.024 & 0.1302 & 0.0425 \\
\hline $\mathrm{ZnO}$ & 0.0169 & 0.0146 & 0.0153 & 0.0392 \\
\hline SrO & 0.0167 & 0.0152 & 0.0239 & 0.028 \\
\hline $\mathrm{ZrO}_{2}$ & 0.0381 & 0.0376 & 0.019 & 0.0223 \\
\hline $\mathrm{CuO}$ & 0.0153 & 0.0152 & n.d. & n.d. \\
\hline $\mathbf{R b}_{2} \mathbf{O}$ & 0.0436 & 0.0417 & n.d. & 0.0355 \\
\hline BaO & n.d. & n.d. & 0.3023 & n.d. \\
\hline $\mathrm{ReO}_{2}$ & n.d. & n.d. & n.d. & n.d. \\
\hline HgO & n.d. & n.d. & n.d. & n.d. \\
\hline $\mathrm{As}_{2} \mathrm{O}_{3}$ & n.d. & n.d. & n.d. & 0.0117 \\
\hline $\mathrm{TeO}_{2}$ & n.d. & n.d. & n.d. & n.d. \\
\hline $\mathrm{V}_{2} \mathrm{O}_{5}$ & n.d. & n.d. & n.d. & n.d. \\
\hline $\mathrm{Co}_{2} \mathrm{O}_{3}$ & n.d. & n.d. & n.d. & n.d. \\
\hline PdO & n.d. & n.d. & n.d. & n.d. \\
\hline
\end{tabular}


Table 2: $\quad$ XRD analysis results of R17, R18, R19 and R25 coded samples and raw materials of clays.

\begin{tabular}{|c|c|}
\hline Sample Code & Minerals/Phases \\
\hline R17 & Quartz, Microcline, Kaliophilite, Hematite, Maghemite. \\
\hline R18 & Quartz, Microcline, Kaliophilite, Hematite, Maghemite. \\
\hline R19 & $\begin{array}{c}\text { Quartz, Plajiyoklas, Illite, Calcite, Wollastonite, Akermanite, } \\
\text { Hematite, Maghemite. }\end{array}$ \\
\hline $\mathbf{R 2 5}$ & $\begin{array}{c}\text { Quartz, Plagioclase, Microcline, Illite, Kaliophilite, Augite, } \\
\text { Gehlenite, Maghemite. }\end{array}$ \\
\hline SNLKKY & $\begin{array}{l}\text { Quartz, Plagioclase, Illite/Muscovite, Montmorillonite, Kaolinite, } \\
\text { Calcite, Dolomite. }\end{array}$ \\
\hline AYVALIB & $\begin{array}{l}\text { Quartz, Plagioclase, Illite/Muscovite, Talc, Kaolinite, } \\
\text { Kaliophilite, Calcite, Dolomite. }\end{array}$ \\
\hline CKOY2B & $\begin{array}{c}\text { Quartz, Plagioclase, Illite/Muscovite, Kaolinite/Montmorillonite, } \\
\text { Calcite. }\end{array}$ \\
\hline IK3A & $\begin{array}{l}\text { Quartz, Plagioclase, Illite/Muscovite, Talc, Montmorillonite, } \\
\text { Kaolinite, Calcite. }\end{array}$ \\
\hline SO1K & $\begin{array}{c}\text { Quartz, Plagioclase, Illite/Muscovite, Montmorillonite, Kaolinite, } \\
\text { Calcite, Dolomite. }\end{array}$ \\
\hline
\end{tabular}

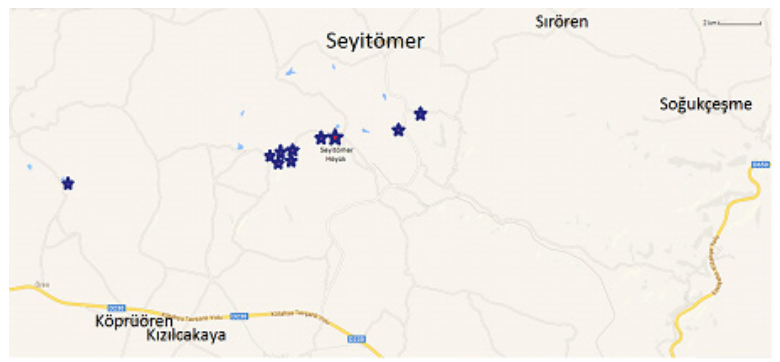

Figure 3: Shows the raw materials (clays) collected around the Seyitömer Mound.

XRD results of the raw materials (clays) collected around the Seyitömer Mound are also given in Table 2. They were coded as SNLKKY, AYVALIB, CKOY2B, IK3A and SO1K.

Quartz is a mineral with high heat of melting. For this reason, quartz mineral exists in all samples. Quartz and feldspars can persist up to $1000^{\circ} \mathrm{C}$ (İssi et al. [7]). Illite/muscovite or mica structure breaks down in the range of $900-1000^{\circ} \mathrm{C}$ (Grimshaw [8]). Calcite minerals are decomposed at $850^{\circ} \mathrm{C}$. R25 coded sample have no calcite mineral. Therefore, sample might be sintered around $850^{\circ} \mathrm{C}$. R19 coded sample includes calcite mineral. It may be fired at lower temperature than decomposition of calcite.

Pyroxenes like diopside and augite may be generated from dolomite and silica reactions at $800-900^{\circ} \mathrm{C}$. Gehlenite may be formed at $850^{\circ} \mathrm{C}$ with the reaction of 
$\mathrm{CaO}$ and illite structure (Cultrone et al. [9]). Gehlenite begins to form at $800^{\circ} \mathrm{C}$ and disappear at $900^{\circ} \mathrm{C}$ (Veniale [10]). Wollastonite may be formed at $800^{\circ} \mathrm{C}$ with the reaction of $\mathrm{CaO}$ and quartz structure (Cultrone et al. [9]). Sintering temperature is pretty much the same with gehlenite. R19 coded sample which contains wollastonite indicates a firing temperature probably at $800^{\circ} \mathrm{C}$. From the decomposition of illite, an intermediate phase originates between spinel $\left(\mathrm{MgO} \cdot \mathrm{Al}_{2} \mathrm{O}_{3}\right)$ and hercynite $\left(\mathrm{FeO} \cdot \mathrm{Al}_{2} \mathrm{O}_{3}\right)$ (Jordan et al. [11]). Considering $\mathrm{R} 17$ and R18 coded samples are clay based fired bodies, sintering temperature could not exceed $1000^{\circ} \mathrm{C}$ due to the absence of spinel or mullit phases for samples possible to be generated below $1100^{\circ} \mathrm{C}$. Hematite phase in XRD pattern are the signs of oxidative firing (Damjanovic et al. [12]). However, existence of maghemite phase on XRD pattern shows reductive atmosphere on firing (Legodi and de Waala [13]).

\subsection{SEM analysis results and discussion}

SEM images of Ca rich and poor samples are given in Figure 4.

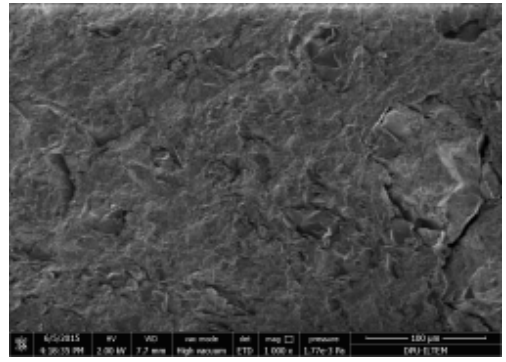

(a)

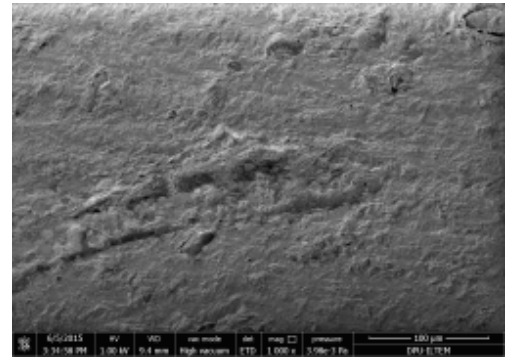

(b)

Figure 4: $\quad$ SEM images of Ca rich R25 coded sample (a) and Ca poor R18 coded sample (b).

Interactions between clay matrix and grains, shape changes of grains, increase of the aggregation rate within the clay matrix with the formation of secondary porosity and formation of intergranular bridges may be occurred with increasing temperature in clay based ceramics. These changes become more evident in calcareous clays than the siliceous materials including clays (Riccardi et al. [14]). Since some of the samples contain high amounts of calcium, SEM images exhibited predominantly arrangements of calcium rich new mineral formations in the microstructure of the samples (Figure 4(a)). Quartz is one of the primary components of clay based ceramics with high melting temperature. It is considered that quartz is relatively insoluble below $1250^{\circ} \mathrm{C}$, dissolution of quartz forms silicarich amorphous solution rims around quartz grains (Iqbal and Lee [15]). Quartz grain dissolution into vitrified clay matrix of the sample may easily be distinguished by the atomic contrast difference in BSE images. Feldspar is believed to melt around $1100^{\circ} \mathrm{C}$ in the contact zone between feldspar crystals and clay relicts and potash matrix require high temperature around $1200^{\circ} \mathrm{C}$. 


\subsection{Thermogravimetric-differential thermal analysis TG-DTA results and discussion}

TG-DTA is one of the convenient methods preferred in characterization of ancient ceramics. This technique allows the examination of changes occurred due to the decomposition, transformation and formation reactions during a controlled heating process (Drebushchak et al. [16]). Samples were heated from room temperature to $1200^{\circ} \mathrm{C}$ with a heating rate of $10^{\circ} \mathrm{C} / \mathrm{min}$ in order to expose the enthalpy changes (plotted by DTA curves with endothermic and exothermic effects) and weight loss/gain (plotted by TG curves).

The endothermic effect from room temperature to $200^{\circ} \mathrm{C}$ is due to the release of hygroscopic water (Maritan et al. [17]). At higher temperatures of $200-300^{\circ} \mathrm{C}$ the endothermic effect depicts the removal of the chemically bound water, but it may not met in the present study (Paama et al. [18]). Depending on the area of the peaks observed in the range of $200-650^{\circ} \mathrm{C}$, the exothermic effect identified within these temperatures was attributed to the combustion of organic materials, not completely burnt during firing in reducing condition and transformed into carbonaceous particles which are thought to be deliberately added into the ceramic paste to increase its plasticity or were contained in the clay utilized in the manufacture (Palanivel and Rajesh Kumar [19]). The endothermic effects observed at $700-875^{\circ} \mathrm{C}$ indicated the decarbonation reactions of mainly calcite and dolomite (Meyvel et al. [20]).

TG-DTA results of selected samples are given in Figures 5 and 6.

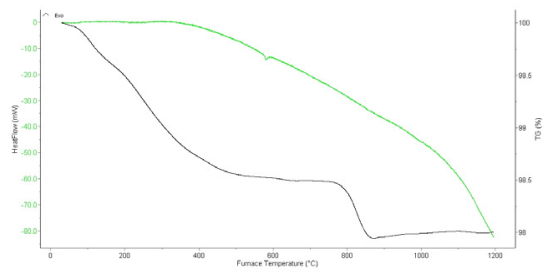

(a)

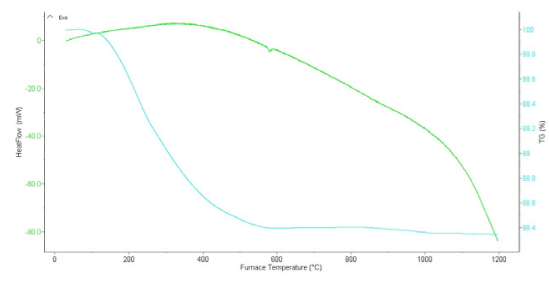

(b)

Figure 5: TG-DTA curve of the sample of R17 (a) and R18 (b).

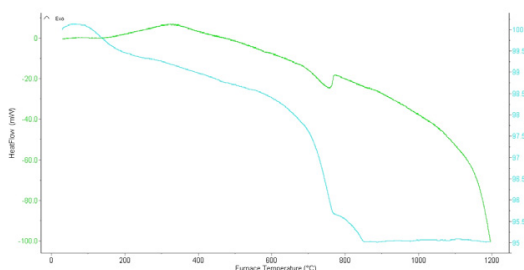

(a)

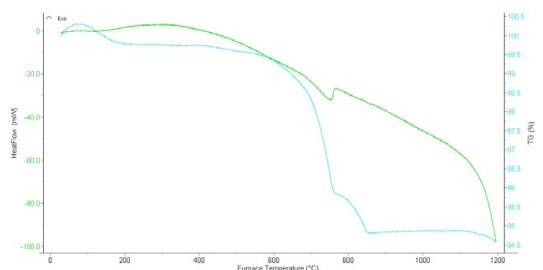

(b)

Figure 6: TG-DTA curve of the sample of R19 (a) and R25 (b). 
R17 coded sample has around 2\% mass loss. Mass change is methodical up to $450^{\circ} \mathrm{C}$. Considering TG analysis with XRD results weight originates from the reactions of unbound or adsorbed water or burning of organic substance. Endothermic reaction in $575^{\circ} \mathrm{C}$ is because of crystal water decomposition on R17 coded sample. As seen from the Figure 5 mass loss peak is around 1.6\% in R18 coded sample. According to TG analysis mass change is methodical up to $420^{\circ} \mathrm{C}$. Endothermic reaction in $575^{\circ} \mathrm{C}$ is because of crystal water decomposition in R18 coded sample. As seen from the Figure 6 mass loss peak is around 5\% in R19 coded sample. Mass change is methodical up to $580^{\circ} \mathrm{C}$. Endothermic reaction at $750^{\circ} \mathrm{C}$ may because of calcite decomposition. Mass loss peak is around $5.5 \%$ in R25 coded sample. Mass change is methodical to $500^{\circ} \mathrm{C}$. Endothermic reaction at $750^{\circ} \mathrm{C}$ in $\mathrm{R} 25$ coded sample may be cause of calcite decomposition again.

\section{Conclusions}

From WDXRF, XRD, SEM and TG-DTA analysis results obtained, the Roman period ceramics unearthed in the Seyitömer Mound have been produced from clay deposits containing illitic type minerals with rich in iron and calcium rich and poor accessory minerals. To compare with regional geological formations and raw material sources, it may be suggested that local raw material source is enough to produce such kind of ceramic wares during the Roman period. According to phases/minerals in Roman period samples firing temperatures are between $600^{\circ} \mathrm{C}$ and $1100^{\circ} \mathrm{C}$.

\section{Acknowledgement}

This study is a part of ongoing project titled "Archaeometrical Characterization of Ceramic Findings Belonging to Achaemenid, Hellenistic and Roman Periods from Seyitömer Mound (Kütahya)" with the project number of 113K096. The Scientific and Technological Research Council of Turkey (TÜBITTAK) is acknowledged.

\section{References}

[1] Papachristodoulou C., Oikonomou A., Ioaniddes K. \& Gravani K., A Study of Ancient Pottery by Means of X-Ray Fluorescence Spectroscopy, Multivariate Statistics and Mineralogical Analysis. Analytica Chimica Acta, 573, pp. 347-353, 2006.

[2] Barone G., Crupi V., Galli S., Majolino D., Migliardo P. \& Venuti V., Spectroscopic İnvestigation of Greek Ceramic Artefacts. Journal of Molecular Structure, 651, pp. 449-458, 2003.

[3] Bilgen, A. N. Seyitömer Höyük Kazısı Ön Raporu. P.1 2011, Kütahya (in Turkish).

[4] Vinagre U. M., Latini R. M., Bellido A. V. B., Buarque A. \& Borges A. M., Ancient Ceramics Analysis by Neutron Activation in Association with Multivare Methods. Brazilian Journal of Physics, 35, pp. 779-781, 2005. 
[5] Demirel M., Sevin F. B., Say R. \& Yazan Y., Propranolol HCl Imprinted Polymeric Microspheres: Development, Characterization and Dissolution. FABAD J. Pharm. Sci., 32, pp. 147-157, Ankara, 2007.

[6] Kennett D. J., Sakai S., Neff H., Gossett R. \& Larson D. O., Compositional Characterisation of Prehistoric Ceramics: A New Approach. Journal of Archaeological Science, 29, pp. 443-455, 2002.

[7] İssi A., Kara A. \& Alp A. O., An Investigation of Hellenistic Period Pottery Production Technology from Harabezikan/Turkey. Ceramics International, 37, pp. 2575-2582, Eskişehir, 2011.

[8] Grimshaw R. W., The Chemistry and Physics of Clays. Techbooks, p. 727, India, 1971.

[9] Cultrone G., Navarro C. R., Sebastian E., Cazalla O. \& Torre M. J., Carbonate and Silicate Phase Reactions during Ceramic Firing. Eur. J. Mineral, 13, pp. 621-634, Stuttgart (Germany), 2001.

[10] Veniale F., Modern techniques of analysis applied to ancient ceramics. In: Advanced workshop on analytical methodologies for the investigation of damaged Stones. Pavia, (Italy), 1990.

[11] Jordan M. M., Boix A., Sanfeliu T., de la Fuente C., Firing transformations of cretaceous clays used in the manufacturing of ceramic tiles. Appl. Clay Sci., 14, pp. 225-234, 1999.

[12] Damjanovic L., Antunovic I. H., Mioc U. B, Bikic V., Milanovic D. \& Evans I. R., Archaeometric study of medieval pottery excavated at Stari (Old) Ras Serbia. J. Archaeol. Sci., 38, pp. 818-828, 2011.

[13] Legodi, M. A. \& de Waala M. A., The preparation of magnetite, goethite, hematite and maghemite of pigment quality from mill scale iron waste. Department of Chemistry, University of Pretoria, v.74, i.1, pp. 161-168, Pretoria (South Africa), 2007.

[14] Riccardi M. P., Messiga B. \& Duminuco P., An approach to the dynamics of clay firing. Appl. Clay Sci., 15, pp. 393-409, 1999.

[15] Iqbal Y. \& Lee W. E., Microstructural evolution in triaxial porcelain. J. Am. Ceram. Soc., 83, pp. 3121-3127, 2000.

[16] Drebushchak V. A., Mylnikova L. N., Drebushchak T. N. \& Boldyrev V. V., The investigations of ancient pottery. J. Therm. Anal. Calorim., 82, pp. 617-626, 2005.

[17] Maritan L., Nodari L., Mazzoli C., Milano A. \& Russo U., Influence of firing conditions on ceramic products: experimental study on clay rich in organic matter. Appl. Clay Sci., pp. 311-315, 2006.

[18] Paama L., Pitkanen I. \& Peramaki P., Analysis of archaeological samples and local clays using ICP-AES, TGDTG and FTIR techniques. Talanta, 51, pp. 349-357, 2000.

[19] Palanivel R. \& Rajesh Kumar U., Thermal and spectroscopic analysis of ancient potteries. Rom. J. Phys., 56, pp. 195-208, 2011.

[20] Meyvel S., Sathya P. \& Velraj G., Thermal characterization of archaeological potsherds recently excavated in Nedunkur, Tamilnadu, India. Cerâmica, 58, pp. 338-341, 2012. 